\title{
Hepatitis B Treatment in Light of Natural Sources
}

\author{
Aisha Shehzad ${ }^{1}$, Abida Hussain ${ }^{1}$, Shifa Iman ${ }^{1}$, Sohail Ahmed ${ }^{2}$ and Faiza Naseer ${ }^{1,3 *}$ \\ ${ }^{1}$ Faculty of Pharmaceutical Sciences, Government College University, Pakistan \\ ${ }^{2}$ Department of Biochemistry, Hazara University, Pakistan \\ ${ }^{3}$ Shifa College of Pharmaceutical Sciences, Shifa Tameer e Millat University, Pakistan
}

Submission: April 11, 2019; Published: May 15, 2019

"Corresponding author: Faiza Naseer, Faculty of Pharmaceutical Sciences, Government College University, Faisalabad, Pakistan

\begin{abstract}
Hepatitis B virus causes acute and chronic inflammation of liver which may leads to hepatocellular carcinoma, cirrhosis and death. Chronic hepatitis B is usually accompanied by the presence of detectable hepatitis B surface antigen (HBsAg) in the blood for greater than 6 months. The presence of hepatitis B envelope antigen ( $\mathrm{HBeAg}$ ) is related to higher rates of viral replication leading to more infection.

Objective: Currently vaccination for prevention of hepatitis B is present and its treatment includes pegylated interferon $\alpha$, lamivudine, telbivudine and entecavir (nucleoside analogues) and adefovir (nucleotide analogues). This treatment is partially effective and has significant dose dependent side effects and resistance after long term use. Hence, there is a need to develop new more safe and potent agents against hepatitis B from medicinal plants.

This review illustrates the description of medicinal plants, family, their active ingredients, parts and extracts used to treat hepatitis B by their mechanisms. The pharmaceutical companies are striving to discover appropriate alternative and natural inhibitors of targeting different steps of HBV life cycle, because single plant contains an invaluable number of active ingredients which could help in the manufacture of pharmaceutical grade proteins and has wide spectrum of antiviral activity. However, information of antiviral activity of plants is still inadequate.

Keywords: Hepatitis B virus; Medicinal plants; HBs Ag; Hepatoprotective activity; Antiviral activity; Pharmaceutical grade proteins; Chronic hepatitis B; Liver cancer; Cirrhosis; Vaccination; Pegylated interferon $\alpha$; Telbivudine; Lamivudine; Adefovir; Terpenoids; Lignans; Phenolic compounds; Polyphenols; Tannins
\end{abstract}

Abbreviations: HBsAg: Hepatitis B Surface Antigen; NLS: Nuclear Localization Signaling; NPC: Nuclear Pore Complex; BN: Boehmeria nivea; HBV: Hepatitis B Virus

\section{Introduction}

Hepatitis B, a devastating ailment is distressing over 2 billion population all over the world. Amongst those more than 360 million people suffering from chronic hepatitis B Lavanchy [1]. Every year, the death rate is 0.5-1.2 million people owing to chronic hepatitis, cirrhosis as well as liver cancer according to WHO. In Pakistan, over 15 million peoples have been infected with hepatitis B because of ignorance of vaccination with carrier rate of 3-5\% (Ott, 2012). HBV is transmitted via blood transfusion, use of unhygienic tools for shaving, unsterilized instruments during surgery as well as use of contaminated syringes [2].

Hepatitis is spread via sexual means owing to several sexual partners as well as via diseased mother to children Enemuor et al. [3]. Patients undergoing dialysis for more than two years are at greater risk for hepatitis Wasley et al. [4]. HBV having eight genotypes such as $\mathrm{A}$ to $\mathrm{H}$ are predominant in numerous areas globally. Genotype A is prevalent globally; B along with C exists in Asia; D in South Europe; E in Africa as well as F and G in USA. Currently, in Central America genotype $\mathrm{H}$ has been invented. White patients with genotype A exhibit greater reduction of HBeAg as well as HBV DNA and unceasing removal of HBeAg seroconversion as compare to patients with genotype $\mathrm{D}$. Patients having genotype $\mathrm{B}$ in Asia, exhibit HBeAg seroconversion in early age are at greater risk of developing hepatitis and demonstrate superior response to interferon as compare to patients of genotype C. Patients having genotype $\mathrm{B}$ are different from those with genotype $\mathrm{C}$ in developing hepatocellular carcinoma Saleem \& Sumi et al. $[4,5]$.

Vaccination against hepatitis $\mathrm{B}$ is available but infection remains prominent in many countries such as India, eastern Asia and Pakistan Chu et al. [7]. Currently several therapeutic agents for instance pegylated interferon $\alpha$, telbivudine, lamivudine, 
adefovir (nucleotide analogues) as well as entecavir (nucleoside analogues) have been used however owing to their adverse effects and resistance, medicinal plants have been used to cure hepatitis B Papatheodoridis et al. [8]. Phyto medicines derived from plants are used throughout the world particularly in developed countries such as in Europe and United States.

Pharmaceutical industries are more interested in phytomedicines due to their importance and demand worldwide. The active ingredients (e.g. terpenoids, lignans, phenolic compounds, polyphenols and tannins etc.) obtained from plants are proved to be effective against HBV Huang \& Aftab et al. $[9,10]$. Therefore, this review focuses on traditional plants used for treatment of HBV. Numerous medicinal plants having active ingredients along with classes for instance terpenoids, alkaloids, lignans, flavonoids as well as polyphenols, have specific mechanism of actions on HBV life cycle are demonstrated in Table 1.

Table 1: Plants with their classes \& active ingredients used in treatment of Hepatitis B.

\begin{tabular}{|c|c|c|c|c|c|c|}
\hline Sr No & $\begin{array}{l}\text { Class with Active } \\
\text { Ingredients }\end{array}$ & $\begin{array}{l}\text { Plant Name \& } \\
\text { Part Used }\end{array}$ & Local Name & Family & Effects & References \\
\hline \multirow[b]{2}{*}{1} & Terpenoids: Astataricusone B & \multirow{2}{*}{$\begin{array}{l}\text { Aster tataricus } \\
\text { (Roots and } \\
\text { rhizomes) }\end{array}$} & \multirow[b]{2}{*}{ Tartarian aster } & \multirow[b]{2}{*}{ Asteraceae } & HBsAg secretion & \multirow{2}{*}{$\begin{array}{c}\text { Zhou et al. } \\
\quad[25]\end{array}$} \\
\hline & $\begin{array}{l}\text { Astataricusone B and } \\
\text { Epishionol }\end{array}$ & & & & $\begin{array}{l}\text { HBeAg secretion HBV DNA } \\
\text { replication }\end{array}$ & \\
\hline 2 & Betulinic acid & Pulsatilla chinensis & Bunge & Ranunculaceae & HBV DNA replication & $\begin{array}{c}\text { Yao et al. } \\
{[26]}\end{array}$ \\
\hline 3 & Pumilaside A & $\begin{array}{l}\text { Artemisia } \\
\text { capillaris }\end{array}$ & $\begin{array}{l}\text { Redstem } \\
\text { wormwood }\end{array}$ & Asteraceae & $\begin{array}{l}\text { HBsAg and HBeAg } \\
\text { secretion HBV DNA } \\
\text { replication }\end{array}$ & $\begin{array}{l}\text { Zhao et al. } \\
\quad[27]\end{array}$ \\
\hline 4 & Artesunate & Artemisia аппиа & Sweet wormwood & Asteraceae & $\begin{array}{l}\text { HBsAg secretion HBV DNA } \\
\text { replication }\end{array}$ & $\begin{array}{l}\text { Xu et al. } \\
{[28]}\end{array}$ \\
\hline 5 & Asiaticoside & $\begin{array}{l}\text { Hydrocotyle } \\
\text { sibthorpioides }\end{array}$ & $\begin{array}{l}\text { Lawn marshpenny } \\
\text { wort }\end{array}$ & Araliaceae & $\begin{array}{l}\text { HBsAg and HBeAg } \\
\text { secretion HBV DNA } \\
\text { replication }\end{array}$ & $\begin{array}{l}\text { Huang et al. } \\
\text { [29] }\end{array}$ \\
\hline 6 & $\begin{array}{l}\text { Dehydroandrographolide and } \\
\text { andrographolide }\end{array}$ & $\begin{array}{l}\text { Andrographis } \\
\text { paniculata }\end{array}$ & $\begin{array}{l}\text { Green chirayta, } \\
\text { King of bitters }\end{array}$ & Acanthaceae & HBV DNA replication & $\begin{array}{l}\text { Chen et al. } \\
\text { [30] }\end{array}$ \\
\hline 7 & Alisol A & $\begin{array}{l}\text { Alisma orientalis } \\
\text { (Rhizomes) }\end{array}$ & $\begin{array}{l}\text { Asian water } \\
\text { plantain }\end{array}$ & Alismataceae & $\begin{array}{l}\text { HBsAg and HBeAg } \\
\text { secretion }\end{array}$ & $\begin{array}{c}\text { Zhang et al. } \\
\text { [31] }\end{array}$ \\
\hline 8 & $\begin{array}{l}\text { Perovskatone A and } \\
\text { demethylsalvicanol }\end{array}$ & $\begin{array}{l}\text { Perovskia } \\
\text { atriplicifolia }\end{array}$ & Russian sage & Lamiaceae & $\begin{array}{l}\text { HBsAg and } \mathrm{HBeAg} \\
\text { secretion }\end{array}$ & $\begin{array}{c}\text { Jiang et al. } \\
\text { [32] }\end{array}$ \\
\hline 9 & $\begin{array}{l}\text { SweriyunnangeninA and } \\
\text { 3-epitaraxerol }\end{array}$ & $\begin{array}{c}\text { Swertia } \\
\text { yunnanensis }\end{array}$ & Felworts & Gentianaceae & $\begin{array}{l}\text { HBsAg and HBeAg } \\
\text { secretion }\end{array}$ & $\begin{array}{l}\text { Cao et al. } \\
\text { [33] }\end{array}$ \\
\hline 10 & $\begin{array}{l}\text { Caudatin 3-0- (3, } \\
\text { 4, 5-trimethoxy) } \\
\text { cinnamoylcaudatin }\end{array}$ & $\begin{array}{l}\text { Cynanchum } \\
\text { auriculatum }\end{array}$ & Leather eater & Apocynaceae & $\begin{array}{l}\text { HBsAg secretion HBV DNA } \\
\text { replication Interfers HBV } \\
\text { enhancers and promoters }\end{array}$ & $\begin{array}{c}\text { Wang et al. } \\
\text { [34] }\end{array}$ \\
\hline 11 & $\begin{array}{c}\text { Alisol A 24-acetate, } 25 \\
\text { anhydro alisol A, } 13 \beta, 17 \\
\beta \text {-epoxy alisol A, alisol B } \\
\text { 23-acetate, alisol F and alisol } \\
\text { F 24-acetate }\end{array}$ & $\begin{array}{l}\text { Alisma orientalis } \\
\text { (Rhizomes) }\end{array}$ & $\begin{array}{l}\text { Asian water } \\
\text { plantain }\end{array}$ & Alismataceae & $\begin{array}{l}\text { HBsAg and } \mathrm{HBeAg} \\
\text { secretion }\end{array}$ & $\begin{array}{c}\text { Zhang et al. } \\
\text { [35] }\end{array}$ \\
\hline 12 & $\begin{array}{c}\text { Glycyrrhizin and } \\
\text { glycyrrhetinic acid (GA) }\end{array}$ & $\begin{array}{l}\text { Glycyrrhizae } \\
\text { glabra (Root) }\end{array}$ & Licorice & Fabaceae & $\begin{array}{l}\text { HBsAg and HBeAg } \\
\text { secretion HBV DNA } \\
\text { replication }\end{array}$ & $\begin{array}{l}\text { Wang et al. } \\
\text { [36] }\end{array}$ \\
\hline 13 & $\begin{array}{c}\text { Phyllaemblicins G6-G8 and } \\
\text { phyllaemblicin }\end{array}$ & $\begin{array}{l}\text { Phyllanthus } \\
\text { emblica }\end{array}$ & Amla & Phyllanthaceae & $\begin{array}{l}\text { HBsAg and HBeAg } \\
\text { secretion }\end{array}$ & $\begin{array}{l}\text { Lv et al. } \\
\text { [37] }\end{array}$ \\
\hline 14 & Methyl helicterate & $\begin{array}{l}\text { Helicteres } \\
\text { angustifolia }\end{array}$ & $\begin{array}{l}\text { Shan zhi ma } \\
\text { (Chinese plant) }\end{array}$ & Malvaceae & $\begin{array}{l}\text { HBsAg and HBeAg } \\
\text { secretion HBV DNA } \\
\text { replication }\end{array}$ & $\begin{array}{l}\text { Huang et al. } \\
\text { [38] }\end{array}$ \\
\hline 15 & $\begin{array}{l}\text { Phyllanthacidoid acid methyl } \\
\text { ester and phyllanthacidoids } \\
\text { A, B, C, D, F, G, H, I and M }\end{array}$ & Phyllanthus acidus & $\begin{array}{l}\text { Malay gooseberry, } \\
\text { star berry }\end{array}$ & Phyllanthaceae & $\begin{array}{l}\text { HBsAg and HBeAg } \\
\text { secretion }\end{array}$ & $\begin{array}{l}\text { Lv et al. } \\
\text { [39] }\end{array}$ \\
\hline 16 & Ursolic acid & $\begin{array}{l}\text { Streblus asper } \\
\text { (Heartwood) }\end{array}$ & Sandpaper tree & Moraceae & $\begin{array}{l}\text { HBsAg and } \mathrm{HBeAg} \\
\text { secretion }\end{array}$ & $\begin{array}{l}\text { Li et al. } \\
{[40]}\end{array}$ \\
\hline
\end{tabular}




\begin{tabular}{|c|c|c|c|c|c|c|}
\hline Sr no & $\begin{array}{l}\text { Class with Active } \\
\text { Ingredients }\end{array}$ & $\begin{array}{l}\text { Plant Name \& } \\
\text { Part Used }\end{array}$ & Local Name & Family & Effects & References \\
\hline 17 & $\begin{array}{l}\text { LIGNANS Schisanwilsonin } \\
\text { D, schisantherin C, } \\
\text { deoxyschizandrin and (+) } \\
\text {-gomisin K3 }\end{array}$ & $\begin{array}{c}\text { Schisandra } \\
\text { wilsoniana (Fruits) }\end{array}$ & Chinese plant & Schisandraceae & $\begin{array}{l}\text { HBsAg and } \mathrm{HBeAg} \\
\text { secretion }\end{array}$ & $\begin{array}{l}\text { Ma et al. } \\
\text { [41] }\end{array}$ \\
\hline 18 & Helioxanthin (HE-145) & $\begin{array}{c}\text { Taiwania } \\
\text { cryptomerioides } \\
\text { (Heartwood) }\end{array}$ & Chinese plant & Cupressaceae & HBV DNA replication & $\begin{array}{l}\text { Tseng et al. } \\
\quad[42]\end{array}$ \\
\hline \multirow[t]{2}{*}{19} & $\begin{array}{l}\left(7^{\prime} \mathrm{R}, 8^{\prime} \mathrm{S}, \mathrm{7}^{\prime \prime} \mathrm{R}, 8^{\prime \prime} \mathrm{S}\right) \text {-erythro- } \\
\text { strebluslignanol G, } \\
\text { magnolol, isomagnolol and } \\
\text { isolariciresinol }\end{array}$ & \multirow{2}{*}{$\begin{array}{l}\text { Streblus asper } \\
\text { (Root) }\end{array}$} & \multirow{2}{*}{ Sandpaper tree } & \multirow{2}{*}{ Moraceae } & $\begin{array}{l}\text { HBsAg and } \mathrm{HBeAg} \\
\text { secretion }\end{array}$ & \multirow{2}{*}{$\begin{array}{l}\text { Li et al. } \\
\text { [43] }\end{array}$} \\
\hline & $\begin{array}{c}\left(7^{\prime} \mathrm{R}, 8^{\prime} \mathrm{S}, 7^{\prime \prime} \mathrm{R}, 8^{\prime \prime} \mathrm{S}\right) \text {-erythro- } \\
\text { strebluslignanol G and } \\
\text { magnolol }\end{array}$ & & & & HBV DNA replication & \\
\hline 20 & 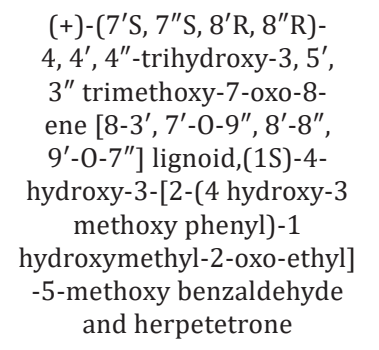 & $\begin{array}{l}\text { Herpetospermum } \\
\text { caudigerm (Seeds) }\end{array}$ & Chinese plant & Cucurbitaceae & $\begin{array}{l}\text { HBsAg and HBeAg } \\
\text { secretion }\end{array}$ & $\begin{array}{c}\text { Yu et al. } \\
\text { [44] }\end{array}$ \\
\hline 21 & $\begin{array}{l}(+) \text {-Cycloolivil- } 4^{\prime}-0-\beta-D \\
\text { glucopyranoside }\end{array}$ & Swertia chirayita & Chirayata & Gentianaceae & $\begin{array}{l}\text { HBsAg and HBeAg } \\
\text { secretion HBV DNA } \\
\text { replication }\end{array}$ & Zhou [45]; \\
\hline 22 & $\begin{array}{l}\text { 9- } \beta \text {-xylopyranosyl- } \\
\text { isolariciresinol and honokiol }\end{array}$ & $\begin{array}{l}\text { Streblus asper } \\
\text { (stem bark) }\end{array}$ & Sandpaper tree & Moraceae & $\begin{array}{l}\text { HBsAg and } \mathrm{HBeAg} \\
\text { secretion }\end{array}$ & $\begin{array}{l}\text { Chen et al. } \\
\text { [47] }\end{array}$ \\
\hline 23 & Niranthin and nirtetralin B & $\begin{array}{l}\text { Phyllanthus niruri } \\
\text { L. }\end{array}$ & Stone breaker & Phyllanthaceae & $\begin{array}{l}\text { HBsAg and } \mathrm{HBeAg} \\
\text { secretion }\end{array}$ & $\begin{array}{l}\text { Liu et al. } \\
\text { [48] }\end{array}$ \\
\hline 24 & $\begin{array}{c}\text { Phenolic Acids: } \\
\text { 3,4-0-dicaffeoylquinic acid, } \\
\text { 4,5-0 dicaffeoylquinic acid, } \\
\text { 3,5-0-dicaffeoylquinic acid, } \\
\text { 3,5-Odicaffeoyl-mucoquinic } \\
\text { acid, 5 O-caffeoylquinic acid, } \\
\text { 3-0-caffeoylquinicacid and } \\
\text { 5-0-(E)-p-coumaroylquinic } \\
\text { acid }\end{array}$ & $\begin{array}{l}\text { Lactuca indica } L . \\
\text { (aerial parts) }\end{array}$ & Indian lettuce & Compositae & Reduced HBV DNA level & $\begin{array}{l}\text { Kim et al. } \\
\text { [49] }\end{array}$ \\
\hline 25 & $\begin{array}{l}\text { 3,4-0-dicaffeoylquinic acid } \\
\text { and 3,5-0 dicaffeoylquinic } \\
\text { acid }\end{array}$ & Laggera alata & $\begin{array}{l}\text { Winged stem } \\
\text { laggera, Lumra }\end{array}$ & Asteraceae & $\begin{array}{l}\text { HBsAg and HBeAg } \\
\text { secretion Decreased HBV } \\
\text { cccDNA content }\end{array}$ & $\begin{array}{l}\text { Wu et al. } \\
\text { [50]; Hao et } \\
\text { al. [51] }\end{array}$ \\
\hline \multirow[b]{2}{*}{26} & Polyphenols: Neolancerin & \multirow{2}{*}{$\begin{array}{c}\text { Swertia } \\
\text { yunnanensis }\end{array}$} & \multirow[b]{2}{*}{ Felworts } & \multirow[b]{2}{*}{ Gentianaceae } & $\begin{array}{l}\text { HBsAg and } \mathrm{HBeAg} \\
\text { secretion }\end{array}$ & \multirow[b]{2}{*}{$\begin{array}{l}\text { Cao et al. } \\
\text { [33] }\end{array}$} \\
\hline & $\begin{array}{c}\text { Norswertianolin, } \\
\text { 1,8-dihydroxy-3,5 dimethoxy } \\
\text { xanthone and neolancerin }\end{array}$ & & & & HBV DNA replication & \\
\hline 27 & $\begin{array}{l}\text { M-hydroxybenzoic acid, } \\
\text { phydroxybenzoic acid, m } \\
\text { hydroxybenzenmethanol, } \\
\text { 3,4-dihydroxybenzoic } \\
\text { acid, ethyl 3,4 dihydroxy } \\
\text { benzoate and ethyl 2,5 } \\
\text { dihydroxybenzoate) }\end{array}$ & Swertia mussotii & Felworts & Gentianaceae & $\begin{array}{l}\text { HBsAg and HBeAg } \\
\text { secretion } \\
\text { HBV DNA replication }\end{array}$ & $\begin{array}{l}\text { Cao et al. } \\
\text { [52] }\end{array}$ \\
\hline 28 & LPRP-Et-97543 & $\begin{array}{l}\text { Liriope platyphylla } \\
\text { (Roots) }\end{array}$ & $\begin{array}{l}\text { Lilyturf, border } \\
\text { grass }\end{array}$ & Asparagaceae & HBV DNA replication & $\begin{array}{c}\text { Huang et al. } \\
\text { [53] }\end{array}$ \\
\hline
\end{tabular}




\section{Advanced Research in Gastroenterology \& Hepatology}

\begin{tabular}{|c|c|c|c|c|c|c|}
\hline Sr no & $\begin{array}{l}\text { Class with Active } \\
\text { Ingredients }\end{array}$ & $\begin{array}{l}\text { Plant Name \& } \\
\text { Part Used }\end{array}$ & Local name & Family & Effects & References \\
\hline 29 & Ellagic acid & $\begin{array}{l}\text { Phyllanthus } \\
\text { urinaria }\end{array}$ & $\begin{array}{l}\text { Chamber bitter, } \\
\text { stone breaker }\end{array}$ & Phyllanthaceae & HBeAg secretion & $\begin{array}{l}\text { Shin et al. } \\
\text { [54] }\end{array}$ \\
\hline 30 & Mulberrofuran G & Morus alba & White mulberry & Moraceae & HBV DNA replication & $\begin{array}{l}\text { Geng et al. } \\
\text { [55] }\end{array}$ \\
\hline 31 & Curcumin & Curcuma longa & Turmeric, haldi & Zingiberaceae & $\begin{array}{l}\text { HBeAg secretion Inhibits } \\
\text { HBV gene expression and } \\
\text { DNA replication }\end{array}$ & $\begin{array}{l}\text { Qi et al. } \\
\text { [56]; } \\
\text { Rechtman } \\
\text { et al. [57] }\end{array}$ \\
\hline 32 & Magnatriol B & Streblus asper & Sand paper tree & Moraceae & $\begin{array}{l}\text { HBsAg and HBeAg } \\
\text { secretion }\end{array}$ & $\begin{array}{l}\text { Chen et al. } \\
\text { [58] }\end{array}$ \\
\hline 33 & Protocatechuic aldehyde (PA) & Salvia miltiorrhiza & $\begin{array}{l}\text { Red sage, chinese } \\
\text { sage }\end{array}$ & Lamiaceae & $\begin{array}{l}\text { HBsAg and HBeAg } \\
\text { secretion HBV DNA } \\
\text { replication }\end{array}$ & $\begin{array}{l}\text { Zhou et al. } \\
\text { [59] }\end{array}$ \\
\hline 34 & Flavonoids: Ellagic acid & Phyllanthus niruri & Stone breaker & Phyllanthaceae & HBeAg secretion & $\begin{array}{l}\text { Shin et al. } \\
\text { [54]; Kang } \\
\text { et al. [60] }\end{array}$ \\
\hline 35 & Wogonin & $\begin{array}{l}\text { Scutellaria } \\
\text { baicalensis }\end{array}$ & Baikal skullcap & Lamiaceae & $\begin{array}{l}\text { HBsAg and HBeAg } \\
\text { secretion HBV DNA } \\
\text { replication }\end{array}$ & $\begin{array}{l}\text { Cui et al. } \\
\text { [24]; Huang } \\
\text { et al. [61] }\end{array}$ \\
\hline 36 & $\begin{array}{l}\text { Lactones: 6-hydroxyl-7- } \\
\text { methoxyl-coumarin }\end{array}$ & $\begin{array}{l}\text { Streblus asper } \\
\text { (Heartwood) }\end{array}$ & Sandpaper tree & Moraceae & $\begin{array}{l}\text { HBsAg and } \mathrm{HBeAg} \\
\text { secretion }\end{array}$ & $\begin{array}{l}\text { Li et al. } \\
\text { [62] }\end{array}$ \\
\hline 37 & $\begin{array}{l}\text { Costunolide and } \\
\text { dehydrocostus }\end{array}$ & $\begin{array}{l}\text { Saussurea lappa } \\
\text { (Root) }\end{array}$ & Kust, kuth & Asteraceae & $\begin{array}{l}\text { HBsAg and HBeAg } \\
\text { secretion }\end{array}$ & $\begin{array}{l}\text { Chen et al. } \\
\text { [58] }\end{array}$ \\
\hline 38 & Herpetosperin B & $\begin{array}{l}\text { Herpetospermum } \\
\text { caudigerum } \\
\text { (Seeds) }\end{array}$ & Beej karela & Cucurbitaceae & HBsAg secretion & $\begin{array}{l}\text { Xu et al. } \\
\text { [63] }\end{array}$ \\
\hline 39 & Artemisinin & Artemisia аппиа & Sweet wormwood & Asteraceae & $\begin{array}{c}\text { HBsAg secretion } \\
\text { HBV DNA replication }\end{array}$ & $\begin{array}{l}\text { Romero et } \\
\text { al. [64] }\end{array}$ \\
\hline 40 & Erythrocentaurin (ET) & $\begin{array}{c}\text { Swertia } \\
\text { yunnanensis }\end{array}$ & Felworts & Gentianaceae & $\begin{array}{l}\text { HBsAg and HBeAg } \\
\text { secretion } \\
\text { HBV DNA replication }\end{array}$ & $\begin{array}{l}\text { Cao et al. } \\
\text { [33]; Geng } \\
\text { et al. [65] }\end{array}$ \\
\hline \multirow[t]{2}{*}{41} & Swerilactones E and F & \multirow[t]{2}{*}{ Swertia mileensis } & \multirow[t]{2}{*}{ Felworts } & \multirow[t]{2}{*}{ Gentianaceae } & $\begin{array}{l}\text { HBsAg and } \mathrm{HBeAg} \\
\text { secretion }\end{array}$ & \multirow{2}{*}{$\begin{array}{l}\text { Geng et al. } \\
\text { [66] }\end{array}$} \\
\hline & Swerilactones H-K & & & & HBV DNA replication & \\
\hline 42 & Clausenidin and nordentatin & Clausena excavata & Pink lime-berry & Rutaceae & HBsAg secretion & $\begin{array}{l}\text { Su et al. } \\
\text { [67] }\end{array}$ \\
\hline 43 & Swerilactones C and D & Swertia mileensis & Felworts & Gentianaceae & $\begin{array}{l}\text { HBsAg and HBeAg } \\
\text { secretion }\end{array}$ & $\begin{array}{l}\text { Geng et al. } \\
\text { [68] }\end{array}$ \\
\hline 44 & $\begin{array}{c}\text { Glycosides: } \\
\text { Astragaloside IV }\end{array}$ & Radix astragali & Milk vetch root & Leguminosae & $\begin{array}{l}\text { HBsAg and HBeAg } \\
\text { secretion }\end{array}$ & $\begin{array}{l}\text { Ren et al. } \\
\text { [69] }\end{array}$ \\
\hline 45 & Saikosaponin C & Bupleuri radix & Chaiku saiko & Umbelliferae & $\begin{array}{c}\text { HBsAg secretion } \\
\text { HBV DNA replication }\end{array}$ & $\begin{array}{l}\text { Chiang et } \\
\text { al. [70] }\end{array}$ \\
\hline 46 & $\begin{array}{l}\text { Alkaloids: } \\
\text { Oxymatrine }\end{array}$ & Sophora flavescens & Ku Shen & Fabaceae & $\begin{array}{l}\text { HBsAg and } \mathrm{HBeAg} \\
\text { secretion } \\
\text { HBV DNA replication }\end{array}$ & $\begin{array}{l}\text { Du et al. } \\
\text { [71]; Cui et } \\
\text { al. [33] }\end{array}$ \\
\hline Sr no & $\begin{array}{l}\text { Class with Active } \\
\text { Ingredients }\end{array}$ & $\begin{array}{l}\text { Plant Name \& } \\
\text { Part Used }\end{array}$ & Local Name & Family & Effects & References \\
\hline 47 & $\begin{array}{l}\mathrm{N}, \mathrm{N} \text {-dimethyltryptamine } \\
\text { N12 oxide }\end{array}$ & $\begin{array}{l}\text { Evodia fargesii } \\
\text { Dode }\end{array}$ & -—- & Rutaceae & HBV DNA replication & $\begin{array}{l}\text { Qu et al. } \\
\text { [72] }\end{array}$ \\
\hline 48 & Oxymatrine & Sophora japonica & $\begin{array}{l}\text { Japanese pagoda } \\
\text { (Chinese tree) }\end{array}$ & Fabaceae & $\begin{array}{l}\text { HBV DNA replication } \\
\text { Decrease resistance }\end{array}$ & $\begin{array}{l}\text { Chen et al. } \\
\text { [33] }\end{array}$ \\
\hline
\end{tabular}




\section{Advanced Research in Gastroenterology \& Hepatology}

\begin{tabular}{|c|c|c|c|c|c|c|}
\hline 49 & Dihydrochelerythrine & $\begin{array}{c}\text { Corydalis saxicola } \\
\text { Bunting }\end{array}$ & Crested lark & Papaveraceae & $\begin{array}{l}\mathrm{HBsAg} \text { and } \mathrm{HBeAg} \\
\text { secretion }\end{array}$ & $\begin{array}{l}\text { Wu et al. } \\
\text { [73] }\end{array}$ \\
\hline 50 & $\begin{array}{l}\text { Cepharanthine hydrochloride } \\
\qquad(\mathrm{CH})\end{array}$ & $\begin{array}{l}\text { Stephania } \\
\text { cepharantha } \\
\text { Hayata. }\end{array}$ & (Chinese plant) & Menispermaceae & $\begin{array}{l}\text { HBeAg secretion HBV DNA } \\
\text { replication }\end{array}$ & $\begin{array}{l}\text { Zhou et al. } \\
\quad[74]\end{array}$ \\
\hline 51 & $\begin{array}{c}\text { Dehydrocavidine, } \\
\text { dehydroapocavidine and } \\
\text { dehydroisoapocavidine }\end{array}$ & $\begin{array}{c}\text { Corydalis saxicola } \\
\text { Bunting }\end{array}$ & (Chinese plant) & Papaveraceae & $\begin{array}{l}\text { HBsAg and HBeAg } \\
\text { secretion }\end{array}$ & $\begin{array}{l}\text { Li et al. } \\
\text { [75] }\end{array}$ \\
\hline 52 & Dauricumidine & Hypser panitida & - - & Menispermaceae & HBsAg secretion & $\begin{array}{c}\text { Cheng et al. } \\
\text { [76] }\end{array}$ \\
\hline 53 & $\begin{array}{c}\text { Flavonoids: } \\
\text { Epigallocatechin-3-gallate } \\
\text { (EGCG) }\end{array}$ & Camellia sinensis & Green tea & Theaceae & $\begin{array}{c}\text { HBV entry } \\
\text { HBsAg and HBeAg } \\
\text { secretion } \\
\text { HBV DNA replication } \\
\text { and has more effect than } \\
\text { lamivudine }\end{array}$ & $\begin{array}{l}\text { Huang et al. } \\
\text { [53] }\end{array}$ \\
\hline 54 & Isooriention & Swertia mussotii & Felworts & Gentianaceae & $\begin{array}{l}\text { HBsAg and HBeAg } \\
\text { secretion } \\
\text { HBV DNA replication }\end{array}$ & $\begin{array}{c}\text { Cao et al. } \\
\text { [52] }\end{array}$ \\
\hline 55 & Wogonin & Scutellaria radix & Skullcaps & Lamiaceae & $\begin{array}{l}\text { HBsAg and HBeAg } \\
\text { secretion } \\
\text { HBV DNA replication }\end{array}$ & $\begin{array}{l}\text { Guo et al. } \\
\text { [77] }\end{array}$ \\
\hline 56 & Luteolin and isovitexin & $\begin{array}{c}\text { Swertia } \\
\text { yunnanensis }\end{array}$ & Felworts & Gentianaceae & $\begin{array}{l}\text { HBsAg and HBeAg } \\
\text { secretion HBV DNA } \\
\text { replication }\end{array}$ & $\begin{array}{l}\text { Cao et al. } \\
\text { [78] }\end{array}$ \\
\hline 57 & Robustaflavone & Rhus succedanea & Wax tree & Anacardiaceae & HBV DNA replication & $\begin{array}{l}\text { Zembower } \\
\text { et al. [79] }\end{array}$ \\
\hline 58 & $\begin{array}{c}\text { Others: } \\
\text { Chrysophanol 8-0- } \beta-\mathrm{D} \\
\text { glucoside, emodin, rhein and } \\
\text { sennoside A }\end{array}$ & Rheum palmatum & $\begin{array}{l}\text { Chinese rhubarb, } \\
\text { turkish rhubarb }\end{array}$ & Polygonaceae & $\begin{array}{l}\text { HBV DNA replication } \\
\text { HBsAg secretion }\end{array}$ & $\begin{array}{l}\text { Li et al. } \\
\text { [80], Sun et } \\
\text { al. [81] }\end{array}$ \\
\hline 59 & $\begin{array}{l}\text { 6-O-Caffeoyl-p- } \\
\text { hydroxyacetophenone-4-0- } \\
\beta \text {-D glucopyranoside }\end{array}$ & $\begin{array}{l}\text { Artemisia } \\
\text { capillaries }\end{array}$ & $\begin{array}{l}\text { Chinese moxa } \\
\text { weed }\end{array}$ & Asteraceae & HBV DNA replication & $\begin{array}{l}\text { Zhao et al. } \\
\text { [82] }\end{array}$ \\
\hline 60 & 7-Dehydroxyl-zinniol & Alternaria solani & $\begin{array}{l}\text { Early blight of } \\
\text { tomato }\end{array}$ & Pleosporaceae & $\begin{array}{l}\text { Moderate activity against } \\
\text { HBV }\end{array}$ & $\begin{array}{l}\text { Ali et al. } \\
\text { [83] }\end{array}$ \\
\hline 61 & $\beta$-Thujaplicinol & $\begin{array}{c}\text { Chamaecyparis } \\
\text { obtusal } \\
\text { (Heartwood) } \\
\end{array}$ & $\begin{array}{c}\text { Western red cedar } \\
\text { trees }\end{array}$ & Cupressaceae & HBV DNA replication & $\begin{array}{l}\text { Hu et al. } \\
\text { [84] }\end{array}$ \\
\hline 62 & $\begin{array}{l}\text { P-Hydroxyacetophenone (p } \\
\text {-HAP) }\end{array}$ & $\begin{array}{c}\text { Artemisia } \\
\text { morrisonensis }\end{array}$ & (Chinese plant) & Asteraceae & $\begin{array}{l}\text { HBV DNA replication } \\
\text { HBsAg secretion }\end{array}$ & $\begin{array}{c}\text { Zhao et al. } \\
\text { [85] }\end{array}$ \\
\hline 63 & Resveratrol and polydatin & $\begin{array}{l}\text { Polygonum } \\
\text { cuspidatum }\end{array}$ & $\begin{array}{l}\text { Knot weed, smart } \\
\text { weed }\end{array}$ & Polygonaceae & $\begin{array}{l}\text { HBeAg secretion HBV DNA } \\
\text { replication }\end{array}$ & $\begin{array}{l}\text { Zhang et al. } \\
{[86]}\end{array}$ \\
\hline 64 & $\begin{array}{c}\text { Luteolin-7-0- } \beta \text {-D } \\
\text { glucopyranoside and luteolin }\end{array}$ & $\begin{array}{l}\text { Glossogyne } \\
\text { tenuifolia }\end{array}$ & (Chinese plant) & Asteraceae & HBsAg secretion & $\begin{array}{l}\text { Wu et al. } \\
\text { [87] }\end{array}$ \\
\hline
\end{tabular}

\section{Pathogenesis of Hepatitis B Virus (HBV)}

HBV, a moderately double stranded (ds) DNA virus has family of hepadnaviridae. This virus contains nucleocapsid having DNA genome of $3.2 \mathrm{~kb}$ and DNA polymerase. Assembled hepatitis $\mathrm{B}$ core antigen form nucleocapsid which is protected by lipid envelope comprising of hepatitis B envelope antigen (HBeAg) as well as hepatitis B surface antigen (HBsAg) Baumert et al. [11]. HBV replication begins when virus enters host cell and releases its DNA into nucleus. First step is attachment of virus having pre S1 receptors at its surface and heparin sulfate proteoglycans on liver cells. Then virus penetrates hepatocytes via endocytosis or fusion which depends on host factors involving the endosome synthesis. Nucleocapsid of virus, having partially double stranded relaxed circular (rcDNA), is secreted into cytoplasm prior to reaching to nucleus of hepatocytes. Capsid brings its rcDNA to nucleus by nuclear pore complex (NPC) which is due to association between nuclear localization signaling (NLS) in C-terminal of capsid protein and nuclear import receptors (importin- $\alpha$ and $\beta$ ). 
After that rcDNA is converted into covalently closed circle DNA (cccDNA) via viral DNA polymerase. ccc DNA is used as template for synthesizing of pregenomic RNA which at that time undergo assembly of viral DNA as well as mRNA results in encoding entirely new viral proteins. During the reverse transcription of pregenomic RNA into complementary DNA, the pregenomic RNA is tainted. Initially HBV surface proteins are formed along with polymerized in rough endoplasmic reticulum. The proteins are transferred into ER and pre golgi sections and growing of nucleocapsid is started. Consequently, whole virus is liberated from host cell for stating new life cycle Lu \& Block [12].

\section{Hepatitis B Virus and Medicinal Plants}

Boehmeria nivea (BN) is traditionally used for curing hepatitis B. For screening of activity of ethanolic extract of leaves of BN against hepatitis B virus in vivo, viremia HBV mice models which were generated by subcutaneous inoculation of hepatoma G tumor cell lines (HepG2 2.2.15) for period of 13 days, were used. A result exhibited that $\mathrm{BN}$ extract given orally and intraperitoneally effectively inhibited the formation of HBV DNA and HBsAg. However intraperitoneal administration suppressed serum HBV DNA levels more than oral Chang et al. [13]. In earlier investigations, ethanolic extract of the roots of BN could diminish the supernatant hepatitis B virus (HBV) DNA in HBV producing HepG2 2.2.15 cells.

Also, ethyl acetate and chloroform fractions of BN leaves inhibited HBeAg and HBsAg secretion in cells of HepG 2.2.15 without any observed cytotoxic effects. Phyllanthus amarus suppressed hepatitis B virus polymerase activity, decreased episomal hepatitis B virus DNA content and suppressed releasing of virus into cells of HepG 2 2.2.15. As a consequence, it inhibited HBV replication. G26 hepatitis B virus transgenic mice did not produce serum HBsAg but neither HBcAg nor virion particles were used to study transcriptional control mechanisms. The hepatic HBsAg mRNA levels were decreased, indicating transcriptional or post-transcriptional down-regulation of the transgene Saleem
\& Lee et al. $[14,15]$. Alternanthera philoxeroides have valuable constituents such as flavones, triterpenoid, anthraquinones, saponins, phytosterols, and organic acids. Numerous oleanolic acid analogues from it have potential against HBV. Two new 6-C-boivinopyranosyl flavones along with three known analogues separated from plant, suppressed HBsAg secretion in HepG 2.2.15 cells.

Oenanthe javanica has traditional use in management of hepatitis in China. Therefore in vitro method i.e. culture of Hep G 2.2.15 cells along with in vivo for instance duck hepatitis B virus (DHBV) infection model were used to investigate anti-HBV activity. Results exhibited that phenolic compounds from ethanolic extract of fruit of this plant significantly blocked HBV replication, HBsAg and HBeAg secretion in Hep G2.2.15 cells line and suppressed DHBV replication in ducks in a dose dependent manner. The concentration of HBsAg and HBeAg in cell culture medium was measured via use of enzyme immune assay after being treated with extract for 9 days. DHBV DNA in duck serum was analyzed by dot blot hybridization assay Huang et al. [16].

Methanolic extracts of leaves of Enicostemma axillare and seeds of Terminalia bellerica, blocked HBV DNA polymerase while methanolic extract of leaves of Hybanthus enneaspermus blocked HBs Ag binding in plasma of patients in vitro using ELISA kits Anbalagan et al. [17]. Alcoholic extract of leaves of Acanthus ilicifolius decreased transaminase levels such as ALT and AST in duck hepatitis B virus serum but did not significantly suppress hepatitis B virus DNA in ducks. Thus, extract had hepatoprotective effect against HBV induced liver damage Naseer \& Wei et al. $[18,19]$. Gymnema sylvestre demonstrated antiviral activity and its active ingredients inhibited HBsAg binding and HBV DNA polymerase Subashini \& Rajendran [20]. Methanolic extract of Mimosa pudica inhibited HBs Ag binding to its receptor at $5 \mathrm{mg} / \mathrm{ml}$ (in vitro) which indicated that it had capability to act as novel entry inhibitor during HBV infection by using hepatitis B positive blood Rohan et al. [21]. Medicinal plants have certain components that targets different steps of life cycle of HBV see Figure 1.

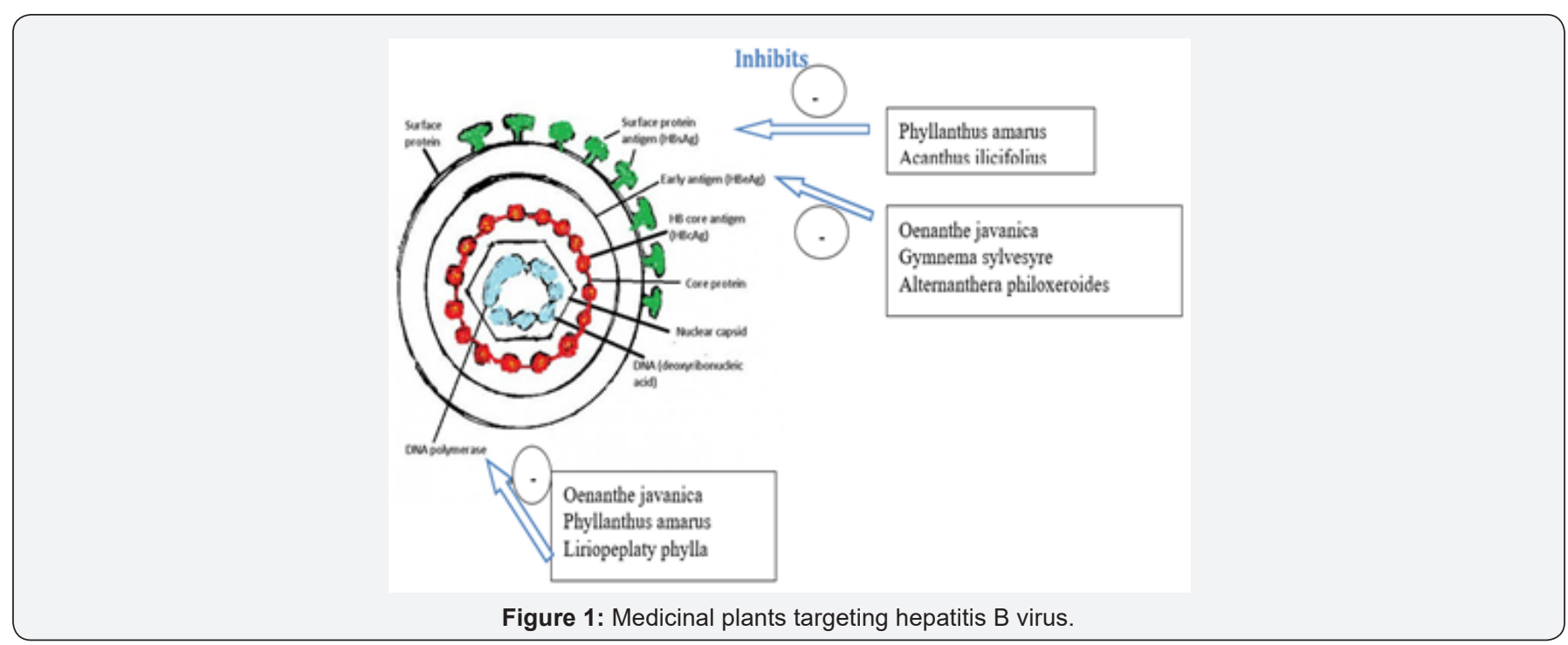


The compound LPRP-Et acquired from Liriope platyphylla roots suppressed HBV by means of monitoring gene expression besides DNA replication via viral proteins which inhibited NF-kB (nuclear factor kappa B) pathway Saleem \& Huang et al. [22,23]. Traditional Chinese medicinal plants such as Phyllanthus, Salvia miltiorrhiza, Rheum palmatum L. and Radix astragali and active ingredients such as oxymatrine, artemisinin and artesunate and wogonin also are effective against hepatitis B Cui et al. [24]. Active ingredients obtained from plants of different classes such as terpenoids, alkaloids, polyphenols, flavonoids and lignans have specific mechanism of action targeting at different steps of life cycle of hepatitis B as shown in Figure 2-5 \& Table 1 [25-88].

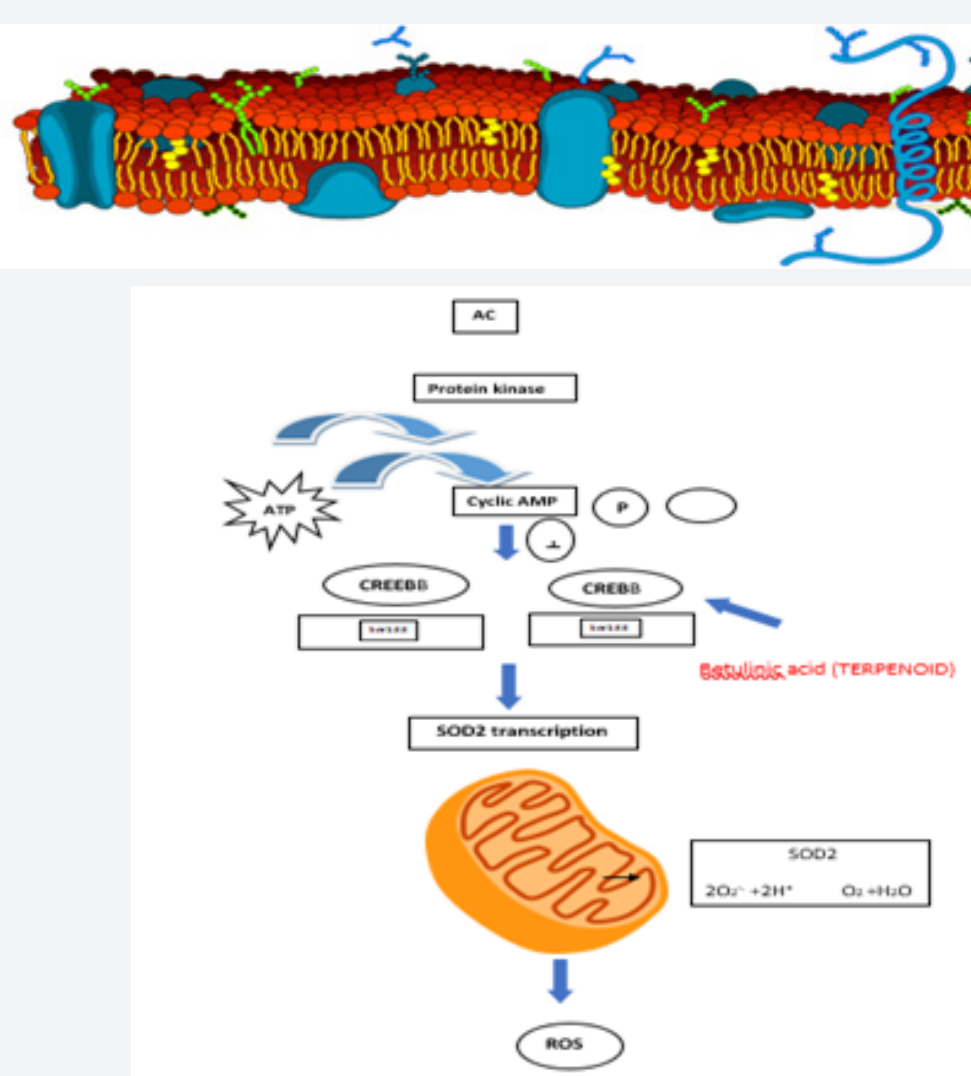

Figure 2: Betulinic acid acquired from Pulsatilla chinensis inhibited replication of HBV via depressing the manganese superoxide dismutase (SOD2) expression within transgenic mice result in formation of reactive oxygen species (ROS) as well as its dysfunction in mitochondria. Newer investigation exhibited that SOD2 expression was reduced via betulinic acid induced dephosphorylation of cAMP response element binding protein (CREB) at Ser133 which transcription factor for SOD2 is transcription. Yao et al. [26].

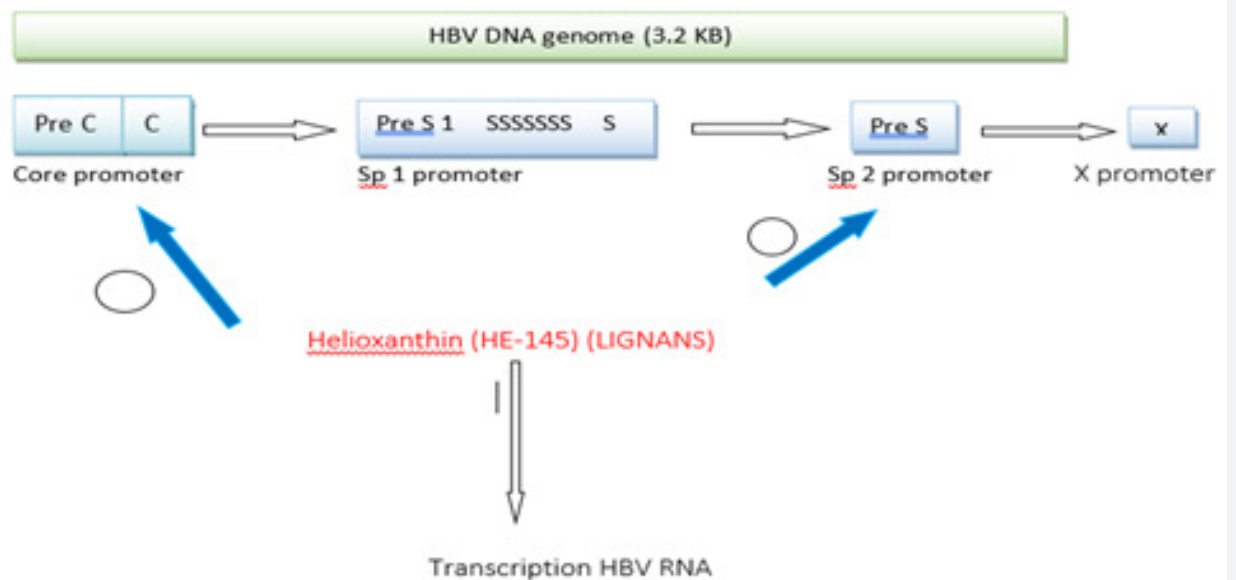

Figure 3: HE-145 inhibited selectively core promoter (CP) and surface antigen promoter II (SPII) but had no effect on $\mathrm{X}$ gene promoter (Xp) and surface antigen promoter I (SPI). Thus, blocks HBV RNA Tseng et al. [42]. 


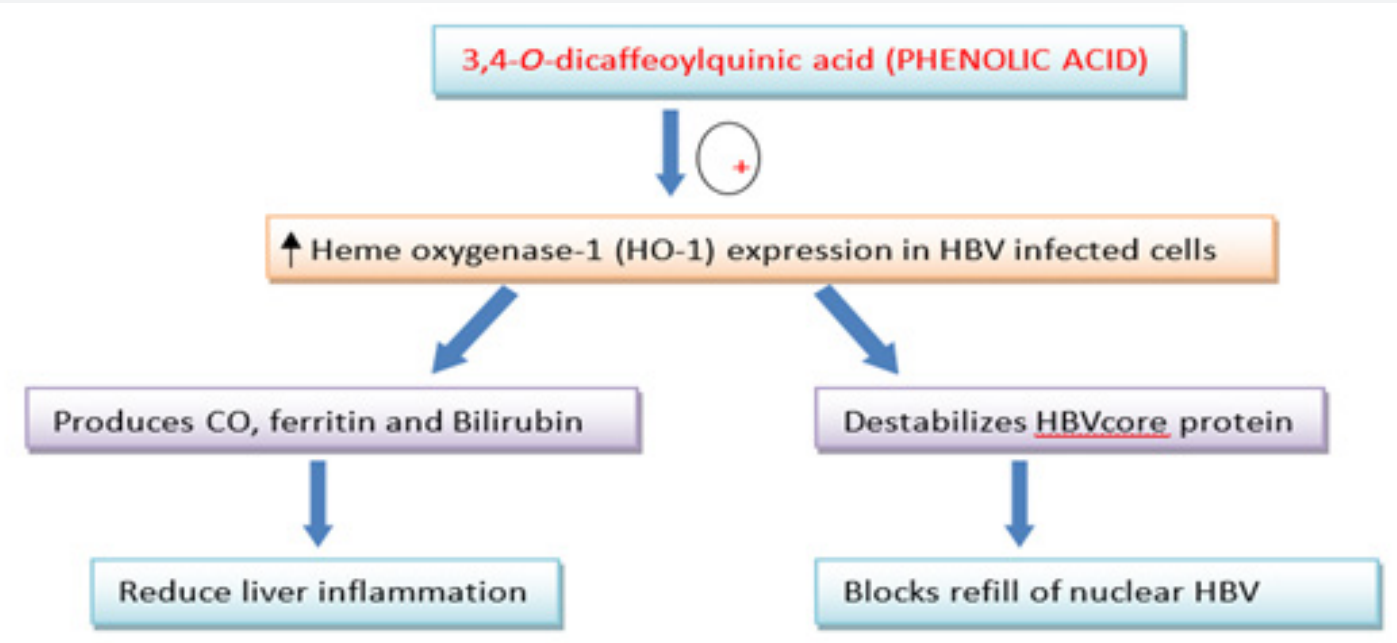

Figure 4: 3,4-O-dicaffeoylquinicacid distinctly reduced hepatitis B viral cccDNA content and considerably increased heme oxygenase-1 (HO-1) expression in HepG 2.2.15 cells and HBV transgenic mice. Because HO-1 can weaken the HBVcore protein and thus prevents refill of nuclear HBV cccDNA Kim et al. [49].

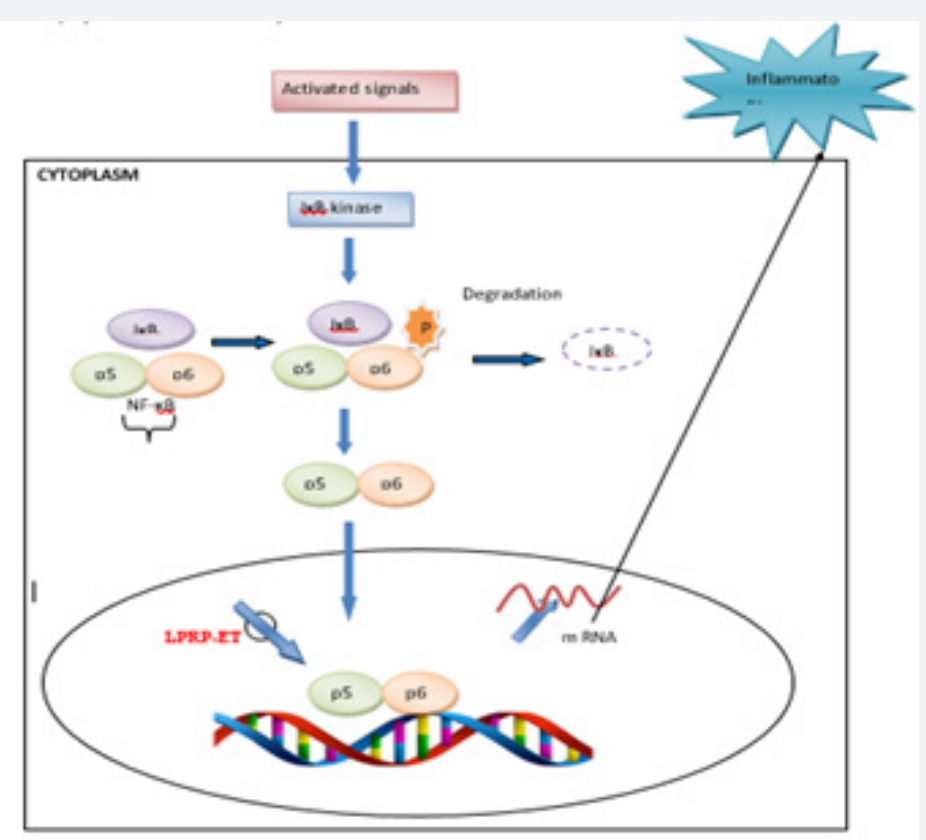

Figure 5: LPRP-Et declinined nuclear expression of p50 as well as p65 proteins from nuclear factor kappa B (NF-kB) and improved level of IKBa protein without distressing the expression within HBV non transfected cells Huang et al. [53].

\section{Conclusion}

Although there are many drugs available for treatment of hepatitis B and vaccination is also effective against virus but due to side effects and resistance associated with these drugs, there is need to explore safer and most potent drugs. Natural products are considered good candidates with strong anti-hepatitis B activity. This review illustrates the description of medicinal plants used to treat hepatitis B. Forthcoming energies should be dedicated to enhancing and progress these principal complexes into effective anti HBV agents for experimental claims. There is limited data available illustrating mechanism of action of medicinal plants with anti-hepatitis B activity. Thus, mechanisms of function and safety of herbs remain incomprehensive and even controversial. The toxicological data for screening the safety of medicinal plants is not discussed and people have blind faith in herbal treatment. For determination of activity of medicinal plants against hepatitis $B$, various HBV animal models for instance HBV transgenic mice and duck model have been used thus, are very expensive but these representations can only describe a portion of the mechanism of anti-hepatitis B medicines. In several findings, cell lines such as HepG 2 2.2.15 within mice were recognized to mimic the occurrence of HBV viremia, for the reason that viruses produced from HepG 2 2.2.15 cells have been defined to be transmittable. 


\section{References}

1. Lavanchy D (2004) Hepatitis B virus epidemiology, disease burden, treatment and current and emerging prevention and control measures. J Viral Hepatol 11: 97-107.

2. Ott JJ (2012) Global epidemiology of hepatitis B virus infection: new estimates of age specific HBsAg seroprevalence and endemicity. Vaccine 30(12): 2212-2219.

3. Enemuor SC, Atabo AR, Oguntibeju OO (2012) Evaluation of microbiological hazards in barbershops in a university setting. Sci Res and Essays 7: 1100-1102.

4. Wasley A, Grytdal S, Gallagher K (2008) Surveillance for acute viral hepatitis United States, 2006. MMWR Morb Mortal Wkly Rep 57(2): 1-24.

5. Saleem M, Naseer F, Ahmad S, Nazish A, Bukhari FR, et al. (2014) Hepatoprotective Activity of Ethanol Extract of Conyza bonariensis against Paracetamol Induced Hepatotoxicity in Swiss Albino Mice. American Journal of Medical and Biological Research 2(6): 124-127.

6. Sumi H, Yokosuka O, Seki N (2003) Influence of hepatitis B virus genotypes on the progression of chronic type B liver disease. Hepatol $37(1): 19-26$

7. Chu D, Yang JD, Lok AS, Tran T, Martins EB, et al. (2013) Hepatitis B screening and vaccination practices in Asian American primary care. Gut Liver 7(4): 450-457.

8. Papatheodoridis GV, Manolakopoulos S, Dusheiko G, Archimandritis AJ (2008) Therapeutic strategies in the management of patients with chronic hepatitis B virus infection. Lancet Infect Dis 8(3): 167-178.

9. Huang TJ, Tsai YC, Chiang SY (2014) Anti-viral effect of a compound isolated from Liriope platyphylla against hepatitis B virus in vitro. Virus Res 192: 16-24.

10. Aftab U. Ahmad M, Taseer A, Faiza N (2015) Hepatoprotective activity of Sonchus asper in paracetamol-induced hepatic damage in rabbits. Bangladesh Journal of Pharmacology 10(1): 511-526.

11. Baumert TF, Meredith L, Ni Y, Felmlee DJ, McKeating JA, et al. (2014) Entry of hepatitis $B$ and $C$ viruses recent progress and future impact. Curr Opin Virol 4: 58-65.

12. Lu X, Block T (2004) Study of the early steps of the Hepatitis B Virus life cycle. Inter J of Med Sci 1(1): 21-33.

13. Chang JM, Huang KL, Yuan TTT (2010) The anti-hepatitis B virus activity of Boehmeria nivea extract in HBV-viremia SCID mice. Evid Based Complement Alternat Med 7(2): 189-195.

14. Saleem M, Naseer F, Ahmad S, Baig K, Irshad I (2015) In vivo cytotoxic effects of methanol extract of Convolvulus arvensis on dimethylbenz(a) antheracene (DMBA) induced skin carcinogenesis. Afr J Pharm Pharmacol 9(12): 397-404.

15. Lee CD, Ott M, Thyagarajan SP (1996) Phyllanthus amarus downregulates hepatitis $\mathrm{B}$ virus mRNA transcription and replication. Eur J Clin Invest 26(12): 1069-1076.

16. Huang ZM, Yang XB, Cao WB (2001) Effects of Qin ling ke li in the treatment of 90 patients with chronic hepatitis B. Pharm J Chinese People's Lib Army 17: 41-44.

17. Anbalagan S, M Sankareswaran, P Rajendran, M Karthikeyan, K Priyadharshini (2015) In vitro screening of anti-HBV properties of selected indian medicinal plants from Kolli hills, Namakkal district of Tamilnadu, India. World J of Pharm and Pharmaceut Sci 4(10): 909915.

18. Naseer F, Ahmad S, Ahmad T, Ashraf MZ (2015) Antioxidant Potential of Leaves of Opuntia monacantha Ethanol Extract and Various Fractions: An in vitro Study. 2015. Global Journal of Pharmacology 9(2): 144-149.
19. Wei PH, Wu SZ, Mu XM (2015) Effect of alcohol extract of Acanthus ilicifolius $L$. on anti-duck hepatitis B virus and protection of liver. J Ethnopharmacol 160: 1-5.

20. Subashini MS, Rajendran P (2015) In vitro screening of anti HBV and anti-HIV properties of Gymnema sylvestre R. Br leaves from Kolli Hills, Tamilnadu, India. Int J Curr Microbiol Appl Sci 4: 542-547.

21. Rohan N, Durgadevi P, Mythily VB, Elanchezhiyan M (2014) Prevention of hepatitis b virus (hbv) replication by extracts of Mimosa pudica, a unique Indian medicinal plant. Bio Info Drug Targets 2(1): 20-23.

22. Saleem M, Imran Qadir M, Ahmad B, Saleem U, Naseer F, et al. (2014) Cytotoxic effect of ethanol extract of Convolvulus arvensis $\mathrm{L}$ (Convolvulaceae) on lymphoblastic leukemia Jurkat cells. Tropical Journal of Pharmaceutical Research 13(5): 705-709.

23. Huang HC, Tao MH, Hung TM, Chen JC, Lin ZJ, et al. (2014) (-)-Epigallocatechin-3-gallate inhibits entry of hepatitis B virus into hepatocytes. Antiviral Res 111: 100-111.

24. Cui X, Wang Y, Kokudo N, Fang D, Tang W (2010) Traditional Chinese medicine and related active compounds against hepatitis $\mathrm{B}$ virus infection. Bio Sci Trends 4(2): 39-47.

25. Zhou WB, Zeng GZ, Xu HM, He WJ, Tan NH (2013) Astataricusones A-D and astataricusol A, five new anti-HBV shionane-type triterpenes from Aster tataricus L. f. Molecules 18(12): 14585-14596.

26. Yao D, Li H, Gou Y, Zhang H, Vlessidis AG, et al. (2009) Betulinic acidmediated inhibitory effect on hepatitis B virus by suppression of manganese superoxide dismutase expression. FEBS J 276(9): 25992614.

27. Zhao Y, Geng CA, Sun CL, Ma YB, Huang XY, et al. (2014) Polyacetylenes and antihepatitis B virus active constituents from Artemisia capillaris. Fitoterapia 95: 187-193.

28. Xu X, Xie H, Hao J, Jiang Y, Wei X (2010) Eudesmane sesquiterpene glucosides from lychee seed and their cytotoxic activity. Food Chem 123: 1123-1126.

29. Huang Q, Zhang S, Huang R, Wei L, Chen Y, et al. (2013) Isolation and identification of an antihepatitis B virus compound from Hydrocotyle sibthorpioides. Lam J Ethnopharmacol 150(2): 568-575.

30. Chen H, Ma YB, Huang XY, Geng CA, Zhao Y, et al. (2014) Synthesis, structure-activity relationships and biological evaluation of dehydroandrographolide and andrographolide derivatives as novel anti-hepatitis B virus agents. Bioorg Med Chem Lett 24(10): 23532359.

31. Zhang Q, Jiang ZY, Luo J, Cheng P, Ma YB, et al. (2008) Anti-HBV agents. Part 1: Synthesis of alisol A derivatives: a new class of hepatitis B virus inhibitors. Bioorg Med Chem Lett 18(16): 4647-4650.

32. Jiang ZY, Huang CG, Xiong HB, Tian K, Liu WX, et al. (2013) Perovskatone A: a novel $\mathrm{C}_{23}$ terpenoid from Perovskia atriplicifolia. Tetrahedron Lett 54(29): 3886-3888.

33. TW Geng CA, Jiang FQ Ma YB, He K, Zhou NJ, et al. (2013) Chemical constituents of Swertia yunnanensis and their anti-hepatitis B virus activity. Fitoterapia 89: 175-182.

34. Wang LJ, Geng CA, Ma YB, Luo J, Huang XY, et al. (2012) Design, synthesis, and molecular hybrids of caudatin and cinnamic acids as novel anti-hepatitis B virus agents. Eur J Med Chem 54: 352-365.

35. Zhang Q, Jiang ZY, Luo J, Liu JF, Ma YB, et al. (2009) Anti-HBV agents. Part 2: synthesis and in vitro anti-hepatitis B virus activities of alisol A derivatives. Bioorg Med Chem Lett 19(8): 2148-2153.

36. Wang LJ, Geng CA, Ma YB, Huang XY, Luo J, et al. (2012) Synthesis, biological evaluation and structure activity relationships of glycyrrhetinic acid derivatives as novel anti-hepatitis B virus agents. Bioorg Med Chem Lett 22(10): 3473-3479. 
37. Lv JJ, Wang YF, Zhang JM, Yu S, Wang D, et al. (2014) Anti-hepatitis $B$ virus activities and absolute configurations of sesquiterpenoid glycosides from Phyllanthus emblica. Org Biomol Chem 12(43): 87648774 .

38. Huang Q Huang R, Wei L, Chen Y, Lv S, et al. (2013) Antiviral activity of methyl helicterate isolated from Helicteres angustifolia (Sterculiaceae) against hepatitis B virus. Antiviral Res 100(2): 373-381.

39. Lv JJ, Yu S, Wang YF, Wang D, Zhu HT, et al. (2014) Anti-hepatitis B virus norbisabolane sesquiterpenoids from Phyllanthus acidus and establishment of their absolute configurations using theoretical calculations. J Org Chem 79(12): 5432-5447.

40. Li LQ Li J, Huang Y, Wu Q Deng SP, et al. (2012) Lignans from the heartwood of Streblus asper and their inhibiting activities to hepatitis B virus. Fitoterapia 83(2): 303-309.

41. Ma WH, Lu Y, Huang H, Zhou P, Chen DF (2009) Schisanwilsonins A-G and related anti-HBV lignans from the fruits of Schisandra wilsoniana. Bioorg Med Chem Lett 19(17): 4958-4962.

42. Tseng YP, Kuo YH, Hu CP, Jeng KS, Janmanchi D, et al. (2008) The role of helioxanthin in inhibiting human hepatitis $B$ viral replication and gene expression by interfering with the host transcriptional machinery of viral promoters. Antiviral Res 77(3): 206-214.

43. Li J, Meng AP, Guan XL, Li J, Wu Q et al. (2013) Anti-hepatitis B virus lignans from the root of Streblus asper. Bioorg Med Chem Lett 23(7): 2238-2244.

44. Yu JQ Hang W, Duan WJ, Wang X, Wang DJ, et al. (2014) Two new antiHBV lignans from Herpetospermum caudigerum. Phytochem Lett 10: 230-234.

45. Zhou NJ, Geng CA, Huang XY, Ma YB, Zhang XM, et al. (2015) Antihepatitis B virus active constituents from Swertia chirayita. Fitoterapia 100: 27-34.

46. Kanchanapoom T, Noiarsa P, Otsuka H, Ruchirawat S (2006) Lignan, phenolic and iridoid glycosides from Stereospermum cylindricum. Phytochemistry 67(5): 516-520.

47. Chen YX, Mao BY, Jiang JH (2002) Relationship between serum load of HBV-DNA and therapeutic effect of oxymatrine in patients with chronic hepatitis B. Zhongguo Zhong Xi Yi Jie He Za Zhi 22(5): 335-336.

48. Liu S, Wei W, Shi K, Cao X, Zhou M, et al. (2014) In vitro and in vivo anti-hepatitis $\mathrm{B}$ virus activities of the lignan niranthin isolated from Phyllanthus niruri L. J Ethnopharmacol 155(2): 1061-1067.

49. Kim KH, Kim YH, Lee KR (2007) Isolation of quinic acid derivatives and flavonoids from the aerial parts of Lactuca indica L. and their hepatoprotective activity in vitro. Bioorg Med Chem Lett 17(24): 67396743.

50. Wu YH, Hao BJ, Cao HC, Xu W, Li YJ, et al. (2012) Antihepatitis B virus effect and possible mechanism of action of 3, 4-o-dicaffeoylquinic Acid in vitro and in vivo. Evid Based Complement Alternat Med 2012: 1-9.

51. Hao BJ, Wu YH, Wang JG, Hu SQ, Keil DJ, et al. (2012) Hepatoprotective and antiviral properties of isochlorogenic acid A from Laggera alata against hepatitis B virus infection. J Ethnopharmacol 144(1): 190-194.

52. Cao TW, Geng CA, Ma YB, Zhang XM, Zhou J, et al. (2015) Chemical constituents of Swertia mussotii and their anti-hepatitis B virus activity. Fitoterapia 102: 15-22.

53. Huang J, Su D, Feng Y, Liu K, Song Y (2014) Antiviral herbs present and future. Infect Disord Drug Targets 14(1): 61-73.

54. Shin MS, Kang EH, Lee YI (2005) A flavonoid from medicinal plants blocks hepatitis B virus-e antigen secretion in HBV-infected hepatocytes. Antiviral Res 67(3): 163-168.

55. Geng CA, Ma YB, Zhang XM, Yao SY, Xue DQ, et al. (2012) Mulberrofuran $\mathrm{G}$ and isomulberrofuran $\mathrm{G}$ from Morus alba $\mathrm{L}$. anti-hepatitis B virus activity and mass spectrometric fragmentation. J Agric Food Chem 60(33): 8197-8202.

56. Qi F, Li A, Inagaki Y, Gao J, Li J, et al. (2010) Chinese herbal medicines as adjuvant treatment during chemo- or radio-therapy for cancer. Biosci Trends 4(6): 297-307.

57. Rechtman MM, Har-Noy O, Bar-Yishay I, Fishman S, Adamovich Y, et al. (2010) Curcumin inhibits hepatitis B virus via down-regulation of the metabolic coactivator PGC- 1alpha. FEBS Lett 584(1): 2485-2490.

58. Chen H, Li J, Wu Q, Niu XT, Tang MT, et al. (2012) Anti-HBV activities of Streblus asper and constituents of its roots. Fitoterapia 83(4): 643-649.

59. Zhou Z, Zhang Y, Ding XR, Chen SH, Yang J, et al. (2007) Protocatechuic aldehyde inhibits hepatitis B virus replication both in vitro and in vivo. Antiviral Res 74(1): 59-64.

60. Kang EH, Kown TY, Oh GT, Park WF, Park SI, et al. (2006) The flavonoid ellagic acid from a medicinal herb inhibits host immune tolerance induced by the hepatitis B virus-e antigen. Antiviral Res 72(2): 100106.

61. Huang RL, Chen CC, Huang HL, Chang CG, Chen CF, et al. (2000) Antihepatitis B virus effects of wogonin isolated from Scutellaria baicalensis. Planta Med 66(8): 694-698.

62. Li B, Guo QL, Tian Y (2016) New anti-HBV C-boivinopyranosyl flavones from Alternanthera philoxeroides. Molecules 21: 336.

63. Xu B, Liu S, Fan XD, Deng LQ, Ma WH, et al. (2015) Two new coumarin glycosides from Herpetospermum caudigerum. J Asian Nat Prod Res 17(7): 738-743.

64. Romero MR, Efferth T, Serrano MA, Castano B, Macias RI, et al. (2005) Effect of artemisinin/artesunate as inhibitors of hepatitis $B$ virus production in an "in vitro" replicative system. Antiviral Res 68(2): 7583.

65. Geng CA, Huang XY, Ma YB, Zhang XM, Chen JJ (2015) Synthesis of erythrocentaurin derivatives as a new class of hepatitis $B$ virus inhibitors. Bioorg Med Chem Lett 25(7): 1568-1571.

66. Geng CA, Wang LJ, Zhang XM, Ma YB, Huang XY, et al. (2011) Antihepatitis $\mathrm{B}$ virus active lactones from the traditional Chinese herb: Swertia mileensis. Chem 17(14): 3893-3903.

67. Su CR, Yeh SF, Liu CM, Damu AG, Kuo TH, et al. (2009) Anti-HBV and cytotoxic activities of pyranocoumarin derivatives. Bioorg Med Chem 17(16): 6137-6143.

68. Geng CA, Zhang XM, Shen Y, Zuo AX, Liu JF, et al. (2009) Swerilactones C and D, anti-HBV new lactones from a traditional Chinese herb: Swertia mileensis. Org Lett 11(21): 4838-4841.

69. Ren S, Zhang H, Mu Y, Sun M, Liu P (2013) Pharmacological effects of astragaloside IV: A literature review. J Tradit Chin Med 33(3): 413-416.

70. Chiang LC, Ng LT, Liu LT, Shieh DE, Lin CC (2003) Cytotoxicity and antihepatitis B virus activities of saikosaponins from Bupleurum species. Planta Med 69(8): 705-709.

71. Du NN, Li X, Wang YP, Liu F, Liu YX, et al. (2011) Synthesis, structureactivity relationship and biological evaluation of novel $\mathrm{N}$-substituted matrinic acid derivatives as host heat-stress cognate 70 (Hsc70) downregulators. Bioorg Med Chem Lett 21(16): 4732-4735.

72. Qu SJ, Wang GF, Duan WH, Yao SY, Zuo JP, et al. (2011) Tryptamine derivatives as novel non-nucleosidic inhibitors against hepatitis B virus. Bioorg Med Chem 19(10): 3120-3127.

73. Wu YR, Ma YB, Zhao YX, Yao SY, Zhou J, et al. (2007) Two new quaternary alkaloids and anti-hepatitis B virus active constituents from Corydalis saxicola. Planta Med 73(8): 787-791.

74. Zhou YB, Wang YF, Zhang Y, Zheng LY, Yang XA, et al. (2012) In vitro activity of cepharanthine hydrochloride against clinical wild-type and 
lamivudine-resistant hepatitis B virus isolates. Eur J Pharmacol 683(13): 10-15.

75. Li HL, Han T, Liu RH, Zhang C, Chen HS, et al. (2008) Alkaloids from Corydalis saxicola and their anti-hepatitis B virus activity. Chem Biodivers 5(5): 777-783.

76. Cheng P, Ma YB, Yao SY, Zhang Q, Wang EJ, et al. (2007) Two new alkaloids and active antihepatitis B virus constituents from Hypserpa nitida. Bioorg Med Chem Lett 17(19): 5316-5320.

77. Guo Q, Zhao L, You Q, Yang Y, Gu H, et al. (2007) Anti-hepatitis B virus activity of wogonin in vitro and in vivo. Antiviral Res 74(1): 16-24.

78. Cao TW, Geng CA, Jiang FQ, Ma YB, He K, et al. (2013) Chemical constituents of Swertia yunnanensis and their anti-hepatitis B virus activity. Fitoterapia 89: 175-182.

79. Zembower DE, Lin YM, Flavin MT, Chen FC, Korba BE (1998) Robustaflavone, a potential non-nucleoside anti-hepatitis $\mathrm{B}$ agent. Antiviral Res 39(2): 81-88.

80. Li Z, Li LJ, Sun Y, Li J (2007) Identification of natural compounds with anti-hepatitis B virus activity from Rheum palmatum L. ethanol extract. Chemother 53(5): 320-326

81. Sun Y, Li LJ, Li J, Li Z (2007) Inhibition of hepatitis B virus replication by Rheum palmatum L. ethanol extract in a stable HBV-producing cell line. Virol Sin 22(1): 14-20.
82. Zhao Y, Geng CA, Chen H, Ma YB, Huang XY, et al. (2015) Isolation, synthesis and antihepatitis $B$ virus evaluation of p-hydroxy acetophenone derivatives from Artemisia capillaris. Bioorg Med Chem Lett 25(7): 1509-1514.

83. Ai HL, Zhang LM, Chen YP, Zi SH, Xiang H, et al. (2012) Two new compounds from an endophytic fungus Alternaria solani. J Asian Nat Prod Res 14(12): 1144-1148.

84. Hu Y, Cheng X, Cao F, Huang A, Tavis JE (2013) $\beta$-Thujaplicinol inhibits hepatitis $B$ virus replication by blocking the viral ribonuclease $\mathrm{H}$ activity. Antiviral Res 99(3): 221-229.

85. Zhang L, Wang G, Hou W, Li P, Dulin A, et al. (2010) Contemporary clinical research of traditional Chinese medicines for chronic hepatitis B in China: An analytical review. Hepatology 51(2): 690-698.

86. Zhang H, Li C, Kwok ST, Zhang QW, Chan SW (2013) A Review of the pharmacological effects of the dried root of Polygonum cuspidatum (Hu Zhang) and its constituents. Evid Based Complement Alternat Med 2013: 208349.

87. Wu MJ, Weng CY, Ding HY, Wu PJ (2005) Anti-inflammatory and antiviral effects of Glossogyne tenuifolia. Life Sci 76: 1135-1146.

88. Chen HC, Chou CK, Lee SD, Wang JC, Yeh SF (1995) Active compounds from Saussurea lappa Clarks that suppress hepatitis B virus surface antigen gene expression in human hepatoma cells. Antiviral Res 27(12): 99-109.

\section{Your next submission with JuniperPublishers will reach you the below assets}

- Quality Editorial service

- Swift Peer Review

- Reprints availability

- E-prints Service

- Manuscript Podcast for convenient understanding

- Global attainment for your research

- Manuscript accessibility in different formats

( Pdf, E-pub, Full Text, audio)

- Unceasing customer service

Track the below URL for one-step submission https://juniperpublishers.com/online-submission.php 